\title{
THE INFLUENCE OF SITUATIONAL LEADERSHIP STYLES, COMPENSATION, AND WORK ENVIRONMENT TOWARD LECTURER JOB SATISFACTION
}

\author{
Qifari Ma'ruf $\mathbf{A l}^{*}$ \\ Masters of Management, University of Mataram, Indonesia \\ Siti Nurmayanti, Sulaimiah, Lecturers \\ Economic Faculty, University of Mataram, Indonesia \\ *E-mail: makrufgifari@gmail.com
}

\begin{abstract}
This study aims to analyze the significance influence of the situational leadership styles, compensation and working environment toward lecturer job satisfaction at University of West Nusa Tenggara. This study used casual associative research. The sample was lecturers at the University of West Nusa Tenggara and the researcher took 59 lecturers. The data collection of this study was sensus sampling. The data analysis used multiple linear regression with SPSS 16.0. The results showed that the situational leadership style had significant positive correlation toward lecturer job satisfaction at University of West Nusa Tenggara. Compensation and working environment also had significant positive correlation toward lecturer job satisfaction at University of West Nusa Tenggara. The finding gave emphasis to the importance of maintaining work atmosphere among the leader and others in campus to increase productivity.
\end{abstract}

\section{KEY WORDS}

Situational leadership styles, compensation, work environment, lecturer job satisfaction.

The success of higher education in all aspects is determined by its human resources mainly the role of lecturers, as one of the main components in education system in higher education (Ramayanto, 2015). Job satisfation according to Robbins (2008) is a positive feeling about other's work as a result of an evaluation of the characteristics. Meanwhile, Jex \& Britt (2002) have stated that job satisfaction is "the level of positive affection of a worker toward job and its situation". Job satisfaction is related to workers' attitude toward their works. This attitude takes place in cognitive and behavioral aspects. According to Hasibuan (2001), there are several factors which influence job satisfaction, namely remuneration which is fair and feasible or proper placement of compensation, in accordance with the expertise, difficult and easy job, atmosphere and working environment, equipment which support work implementation, leader's attitude to lead and the nature of the job whether or not monotonous.

Leadership style is behaviour that is shown when a person affects another's activities (Hersey \& Blanchard, 2002). It can be said that the leadership focused on what is done by the leaders, which is the process by which the leader explains the purpose of the organizations to others. The leadership style which can enhance and give change to the employees in organization is a situational leadership style. This leadership style emphasizes toward the followers and their level of maturity (Ivancevich, Konopaske \& Matteson, 2007). In other words, situational leadership style is ways of leadership of the leaders to guide, implement, direct, support the subordinates to achieve goals and utilize all abilities by combining existing situations with regard to the behavior of the leaders and their subordinates.

This research started from the research gap, in which the research conducted by Rusmanto (2014) and Jai Prakash (2010) have revealed that the situational leadership style has no effect toward employee job satisfaction. However, other studies showed that 
situational leadership had a positive and significant influence on employee job satisfaction (Chen-Tsang, 2011; Slamet et al., 2013).

In an organization, there are other factors which can affect employee satisfaction. In addition to a leadership style, compensation received by employees is also affect. Robbins and Judge (2008) have stated that compensation plays an important role to determine employee job satisfaction. Compensation is a fixed amount of money paid to employees in return for work performed. According to the previous research conducted by Anas (2013), Dhermawan et al., (2013), and Rizal (2015) showed that compensation has a significant effect on employee job satisfaction. Compensation is one of the motivations for employees to work. The form of compensation such as intrinsic and extrinsic, have a significant effect toward lecturer job satisfaction (Murgijanto, 2015). On the other hand, Rusmanto (2014) and Sari \& Ardana (2016) showed that direct compensation has a negative and not significant effect on performances of employee. In line with Muguongo, Muguna \& Muriithi (2015), it showed that teachers in secondary schools in one of the cities in Kenya were very dissatisfied with all forms of compensation (basic salary and allowance).

Working environment is one of the important factors that may affect employee satisfaction. Sarwono (2005) has stated that working environment is a way that the employees do their daily works. A conducive working environment provides security and allows the employees to work optimally. The previous studies conducted by Anas (2013), Arta \& Harsono (2014), Plangiten (2013), and Rizal (2015) have revealed that working environment had significant positive influence toward work satisfaction. Other studies revealed that non physical working environment affect significantly lecturer job satisfaction. Meanwhile, some studies found that a partially working environment did not have significant influence toward employee satisfaction (Mu'at \& Juliana, 2012; Dhermawan, et al., 2013; Suryana, 2015).

University of West Nusa Tenggara as one of the private universities in Indonesia, managed by Directorate General of Higher Education recorded in Private University Coordinator 8. University of West Nusa Tenggara was established in November 10, 1999 with the number SK PT 89 DO 2001 on July 15, 2005. This university is located on TawakTawak Street, Karang sukun, Mataram, West Nusa Tenggara, Indonesia. Currently, there are six departments of undergraduate program, as well as six faculties with educational accreditation C (source: UNTB, 2017).

In the early observation, there was a gap related to lecturer job satisfaction at University of West Nusa Tenggara, such as lecturers' attitude in a way of accepting the duties given by the organization. Meanwhile, there was no discipline in doing the tasks. If this happened continually, it gives impact on the organization output quality. This caused by lack of support from working environment. On the other hand, the salary or compensation received by the private university lecturers in West Nusa Tenggara was low. The foundation have not been able to conduct high payroll system, because its financial factor. In terms of working environment at university of West Nusa Tenggara, physical working environment and non physiscal working environment include workplace design, lighting as well as the relationship between superiors, subordiantes, and co-workers, still indicated quite comfortable, in other words, working environment had not fully created work satisfaction for the employees in campus.

Based on the research gap and phenomenon, this research aims to analyze and seek the significance influence of situational leadership style, compensation, and working environment toward lecturer job satisfaction at University of West Nusa Tenggara.

\section{LITERATURE REVIEW}

The Relationship between Situational Leadership and Job Satisfaction. The role of a leader in an organization is very dominant. However, leaders should not ignore the importance of the role of labor or employees. Employees or subordinates are one of the executors of various kinds of work and tasks which surely require continuous encouragement to increase their passion and work spirit (Cahyo, 2016). One of the Situational Leadership 
theories is that proposed by Hersey and Blanchard's, known as the Situational Leadership Model. This theory was originally called the life cycle theory of leadership. Leaders need to change their behavior according to the level of readiness or maturity of the subordinates/ followers. The focus of this theory lies in two leader behaviors which are similar to the dimensions of initiating structure and consideration spearheaded by researchers from Ohio State University, namely: a) Task behavior, which shows the extent to which leaders attempt to explain the tasks and obligations of individuals or groups. This behavior includes: telling what to do, how, when and where to do it and who will do it, b) Relationship behavior, which shows the extent to which the leader tries to conduct two-way communication or communication in many directions. This behavior includes: listening, facilitating, and providing support (Marwansyah and Mukaram, 2000).

Luthans (2002) in Path Goal Relationship has stated that leader behavior has an influence on motivation and perception, then effect on job performance and satisfaction. Situational leadership style has a relationship in employee job satisfaction, according to Tiffan in As'ad (2000) job satisfaction is closely related to employees' attitudes towards his work, working situation, cooperation between leader and employee so that a good and conducive work situation can cause individual satisfaction for each employee. According to Luthans (2002), job satisfaction is a positive feeling that is formed by a person's point of view toward a job. Job satisfaction is a feeling that is carried out by employees towards work and everything related to the job.

One leadership style that can advance employees and provide change in the organization is situational leadership style. In which situational leadership seeks to invite members to change, for good and for the sake of advancing together, this kind of behavior can bring subordinate satisfaction into work (Hartanto, 2008). Several studies, Muttaqien (2014) and Plangiten (2013), revealed that leadership and leadership style had a significant effect on employee job satisfaction. Furthermore, the results of research by Kertiriasih, Sujana \& Suardika (2018) had revealed that leadership style had a positive and significant effect on the job satisfaction of employees in companies located in Bali.

So that the first hypothesis can be formulated as follow:

H1: Situational Leadership Style influences Job Satisfaction.

The Relationship between Compensation on Job satisfaction. Martoyo (2000) has stated that job satisfaction is an employee's emotional state meet the value of employee compensation from the company and the level of remuneration desired by the employee. The task of lecturers is not only teaching, but also conducting research and community service. Therefore, the lecturers can conduct their duties properly, as stated by Handoko (2004) if compensation is given correctly, the lecturers will be more satisfied and motivated to achieve organizational goals. Therefore, if the lecturers consider that compensation is inadequate, work performance, motivation and job satisfaction can drop dramatically.

Handoko (2001) has stated that compensation can increase employee job satisfaction. According to Triton (2005), compensation is one of the efforts made by management to improve work performance, work motivation and employee job satisfaction. Compensation can be in the form of wages per hour, day, or periodic salary. According to Triton (2005), the purpose of compensation is to improve job satisfaction. The purpose of job satisfaction is to satisfy the employees who finished their jobs because the compensation means appreciate, and also fulfill their physical, social status needs.

A good work compensation system is a system that is able to guarantee the satisfaction of employees which ultimately allows the company to obtain, and employ a number of people with various attitudes and behaviors and work productively for the interests of the company (Putranto, 2012). If a company is unable to provide compensation to what is expected by employee, his satisfaction will be low and can negatively affect the company. Research conducted by Dhermawan et al., (2013), Arta \& Harsono (2014), and Darma \& Supriyanto (2017) had revealed that compensation has a significant effect on employee job satisfaction. In connection with the results of the study, the second hypothesis can be formulated as follow:

H2: Compensation has an effect on Job Satisfaction. 
The Relationship between Work environment on Job Satisfaction. Working environment is one of the factors which influence employee job satisfaction. If working environment gives an uncomfortable impression, employees will feel lazy to work. This is similar as stated by Nitisemito in Sugiyarti (2012), working environment is everything that is around the workers that can affect them in carrying out their duties. Robbins in Fathonah \& Utami (2010) have stated that employees will work optimally if working environment is comfortable and supportive. According to Leshabari et al., (2008) a supportive working environment helps workers to perform normal tasks more effectively, utilizing their knowledge, skills, and competencies as well as available resources to provide high-quality services.

A study from Plangiten (2013) revealed that working environment had an influence on job satisfaction. According to Hasibuan (2001), there are several factors that influence job satisfaction, one of which is the atmosphere and working environment. Other opinions also stated that the pleasure of working employees is influenced by several factors in working environment that exist in the organization (Masdani in Anoraga, 2009). A study from Agbozo et al., (2017) concluded that working environment had a significant influence on employee satisfaction. The results of this study emphasized the need for management to improve working environment of employees to increase productivity. So that the third hypothesis can be formulated as follow:

H3: Working Environment influences Job Satisfaction.

\section{METHODS OF RESEARCH}

The type of research used is causal associative research which studies the relationship of one or more variables to other variables. The population of this study is all lecturers who teach at the University of West Nusa Tenggara (UNTB). In this study used sensus method as sampling, where all available populations were made as respondents, so that the respondents in this study were 59 lecturers at the University of West Nusa Tenggara (UNTB).

The instrumen testing of this study was based validity and reliability test with using the statistic program namely Statistical Package For Social Science 16 (SPSS 16). The results of validity test from four instrumens of this study show that has a valid with level above the $r$ table value $(>0,30)$, meaning that the four variables can be further analyzed by the next analysis because all indicators are declared valid. While the reliability test results can be seen that the Cronbach Alpha value in each variable shows the required value that is above the value 0.60 , thus the entire statement in the Reliable questionnaire and has met the minimum requirement is 0.60 .

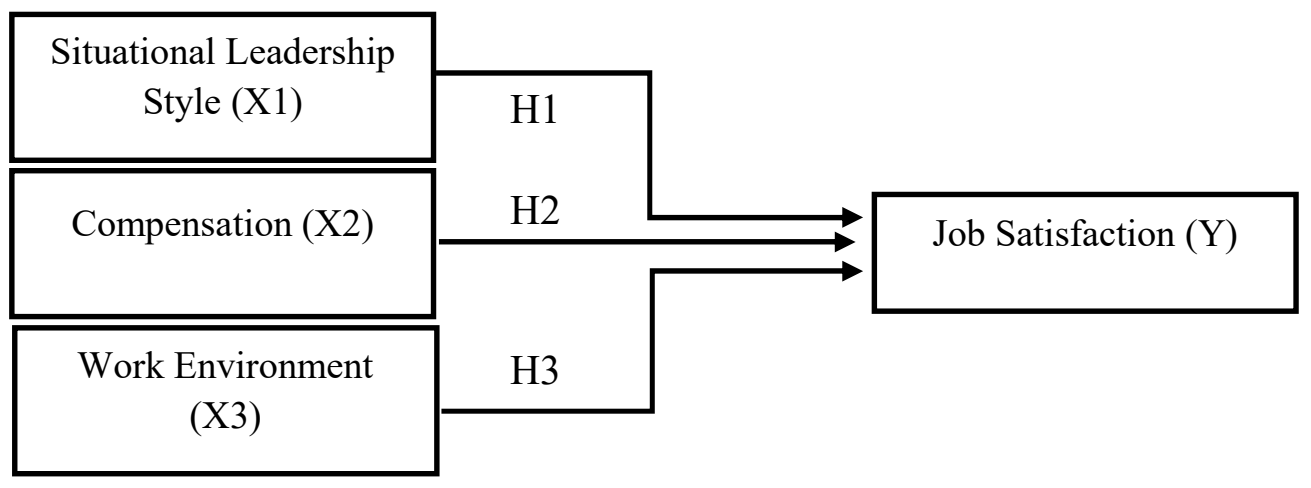

Figure 1 - Hypothesis Model

\section{RESULTS AND DISCUSSION}

In this study using 59 responden as a sample of research collected through questionnaires. 
Table 1 - Characteristics of respondents

\begin{tabular}{llll}
\hline Characteristics of respondents & & Amount (person) & Persentage (\%) \\
\hline Age (years) & $<30$ year & 14 & 23.7 \\
& $30-40$ year & 25 & 42.4 \\
& $>40$ year & 20 & 33.9 \\
& Total & 59 & 100 \\
\hline Gender & Male & 30 & 50.8 \\
& Female & 29 & 49.2 \\
& Total & 59 & 100 \\
\hline Level of education & Master (S2) & 44 & 74,6 \\
& Doctor (S3) & 15 & 25,4 \\
& Total & 59 & 100 \\
\hline Working period & $<5$ year & 25 & 42.4 \\
& $5-10$ year & 17 & 28.8 \\
& $>10$ year & 17 & 28.8 \\
& Total & 59 & 100 \\
\hline
\end{tabular}

Source: research result.

Based on Table 1, it can be seen that most of the lecturers at the University of West Nusa Tenggara (UNTB) who became respondents in this study were between 30-40 years old reaching 42.4 percent or 25 people while respondents with age $>40$ years reached 33.9 percent or 20 respondents. The table above also shows that the majority of research respondents were dominated by respondents with male gender. While based on the level of education, it can be seen that almost a portion of respondents, namely lecturers who work at the University of West Nusa Tenggara (UNTB), have a higher education level, namely Master (S2) as much 44 people or around 74.6. While the other lecturers is doctor program (S3). Judging from the working period, it can be seen that the majority of respondents, namely lecturers who work at the University of West Nusa Tenggara (UNTB), have a majority of $<5$ years of service reaching 42.4 percent or as many as 25 respondents. While respondents with tenure of 5-10 years to more than 10 years amounted to 28.8 percent.

The hypothesis testing in this study was conducted using the SPSS 16.0 program to analyze the relationship between the influence of situational leadership style (X1) compensation (X2) and work environment (X3) on job satisfaction (Y) at the University of West Nusa Tenggara. The multiple regression model in this study is shown as follows:

Table 2 - Multiple Regression Results

Coefficients $^{a}$

\begin{tabular}{l|l|l|l|l|l|l}
\hline \multirow{2}{*}{ Model } & \multicolumn{2}{|l|}{ Unstandardized Coefficients } & Standardized Coefficients & & \\
\cline { 2 - 5 } & $\mathrm{B}$ & Std. Error & Beta & $\mathrm{t}$ & Sig. \\
\hline \multirow{2}{*}{1} & (Constant) & -.714 & .418 & & -1.155 & .253 \\
\cline { 2 - 5 } & Situational Leadership Styles (X1) & .361 & .165 & .261 & 2.188 & .033 \\
\hline Compensation (X2) & .363 & 185 & .242 & 2.060 & .049 \\
\hline Work Environment (X3) & .327 & .154. & .256 & 2.129 & .038 \\
\hline
\end{tabular}

a. Dependent Variable: Job Satisfaction $Y$

Source: SPSS 16.0 analysis.

Based on Table 2 above, a regression equation of the dependent and independent variables can be formed as follows:

$$
Y=-0.714+0.361 X_{1}+0.363 X_{2}+0.327 X_{3}+e
$$

Model feasibility test if the results are significant then this test can be used to predict the model. To see how the regression model is feasible to find out the influence of the situasional leadership style variables, compensation and work environment for lecturer satisfaction at the University of West Nusa Tenggara the F test was used. 
Table 3 - Result of Feasibility Test of Multiple Linear Regression Models

ANOVA $^{\mathrm{b}}$

\begin{tabular}{|c|c|c|c|c|c|c|}
\hline \multicolumn{2}{|c|}{ Model } & \multirow{2}{*}{$\begin{array}{l}\text { Sum of Squares } \\
7.356\end{array}$} & \multirow{2}{*}{$\frac{d f}{3}$} & \multirow{2}{*}{$\begin{array}{l}\text { Mean Square } \\
2.452\end{array}$} & \multirow{2}{*}{$\begin{array}{l}\mathrm{F} \\
7.785\end{array}$} & \multirow{2}{*}{$\begin{array}{l}\text { Sig. } \\
.000^{\mathrm{a}}\end{array}$} \\
\hline 1 & Regression & & & & & \\
\hline & Residual & 17.322 & 55 & .315 & & \\
\hline & Total & 24.678 & 58 & & & \\
\hline
\end{tabular}

a. Predictors: (Constant), X3, X2, X1

b. Dependent Variable: $Y$

Source: SPSS 16.0 analysis.

Based on table 3 , the above can be obtained by F-test 7,785 . The model feasibility test can be seen as a comparison of the F-test > F-table (F-test 7.785) > (F-table with df-3, significant level of $0.05=2.76$ ). Because the value of $F$ (test) $>F$ (table) with a significant level of 0,000 is smaller than 0.05 . These results indicate that the regression model used can be said to fulfill the feasibility assumption of a research model with the data analyzed.

The coefficient of determination $\left(R^{2}\right)$ essentially measures how far the ability of the model in explaining the variation of the dependent variable. The results of the calculation of the coefficient of determination $\left(R^{2}\right)$ variables of situational leadership style, compensation and work environment on job satisfaction in this study are presented in the following table:

Table 4 - Coefficient of determination results (R-Square)

Model Summary ${ }^{\mathrm{b}}$

\begin{tabular}{lllll}
\hline Model & $\mathrm{R}$ & $\mathrm{R}$ Square & Adjusted R Square & Std. Error of the Estimate \\
\hline 1 & $.546^{\mathrm{a}}$ & .298 & .260 & .561 \\
\hline
\end{tabular}

a. Predictors: (Constant), x3, x2, x1

b. Dependent Variable: $Y$

Source: SPSS 16.0 analysis.

Based on table 4 above, the number $\mathrm{R}=0.546$ shows that there is a strong correlation or relationship between the variables of situational leadership style (X1), compensation (X2) and work environment (X3), to the job satisfaction of lecturers contributing $54,6 \%$ is a closely relationship, the higher the $\mathrm{R}$ value, the closer the relationship.

Proof of the hypothesis that has been compiled is done using regression calculations through the help of SPSS version 16.0. The direction and strength of the relationship between the independent variable situational leadership style, compensation and work environment with the dependent variable job satisfaction in this study can be seen from the $t$ test value and significance level.

Table 5 - Results of Hypothesis

\begin{tabular}{|c|c|c|c|c|}
\hline & Standardized Coefficients & & & Conclusion \\
\hline Hypothesis & Beta & $\mathrm{t}$ & Sig. & \\
\hline $\begin{array}{l}\text { Situational Leadership Styles }(X 1) \rightarrow \text { Job } \\
\text { Satisfaction }(Y)\end{array}$ & .261 & 2.188 & .033 & Significant \\
\hline Compensation $(\mathrm{X} 2) \rightarrow$ Job Satisfaction $(\mathrm{Y})$ & .242 & 2.060 & .049 & Significant \\
\hline Work Environment $(\mathrm{X} 3) \rightarrow$ Job Satisfaction $(\mathrm{Y})$ & 256 & 2.129 & .038 & Significant \\
\hline
\end{tabular}

Source: SPSS 16.0 analysis.

From the table above it can be explained that all three independent variables that will prove the significance or failure of each independent variable can be explained as follows:

Effect of Situational Leadership Style on Job Satisfaction. Based on the tests carried out from table 5 , that the results of hypothesis testing from situational leadership style 
variables show t-test of 2.188 with a significance level of 0.033 which is greater than the value of $\mathrm{t}$ table $(\mathrm{t}(\alpha / 2)(\mathrm{n}-2)=\mathrm{t}(0.05 / 2)(59-2)=\mathrm{t}(0.025,57)=\mathrm{t}$-table 2.002 , then Ho is rejected and $\mathrm{Ha}$ is accepted, thus it can be concluded that the first hypothesis have a significant influence between the situational leadership style on satisfaction of Lecturers at the University of West Nusa Tenggara, be accepted.

The results of this study support the research of Fonda et.al., (2015), Wirda \& Azra (2012), Chen-Tsang (2011); Slamet et al., (2013) where research results suggest that situational leadership style influences job satisfaction. Also supporting the findings of Fonda et al., (2015), addressing that situational leadership style has a significant effect both directly and indirectly on employee satisfaction. Rivai (2010) defines leadership as a process of directing and influencing activities that are related to the work of group members. However, the results of this study not support Rusmanto (2014), the results of the study indicate that situational leadership style not affect on job satisfaction. The role of an effective leader in an organization has a very vital role in achieving organizational goals including giving satisfaction to employees through various forms of policy.

Effect of Compensation on Job Satisfaction. Based on the tests carried out from table 5 , that the results of hypothesis testing from compensation variables show t-test of 2,060 with a significance level of 0,049 which is greater than the value of $t$ table $(t(\alpha / 2)(n-2)=t(0.05 / 2)$ $(59-2)=\mathrm{t}(0.025,57)=\mathrm{t}$-table 2,002 then $\mathrm{Ho}$ is rejected and $\mathrm{Ha}$ is accepted, thus it can be concluded that the second hypothesis have a positive and significant influence between compensation on satisfaction of Lecturers at the University of West Nusa Tenggara, be accepted.

This study supports the results of research by Anas (2013), Dhermawan et al., (2013), Muttaqien (2014), Rizal (2015), where compensation has a significant effect on employee job satisfaction. Similarly with study by Arta \& Harsono (2014) compensation has a positive and significant effect on job satisfaction. Murgijanto (2015), intrinsic and extrinsic compensation have a significant effect on lecturer job satisfaction. Mu'at \& Juliana (2012) stated that compensation significant effect simultaneously. While partially it has a weak or insignificant prediction power.

Based on the results of the respondents data processing, it was found that the compensation received by the lecturers at the University of West Nusa Tenggara was in a fairly decent category. This is reflected in several indicators that are used as benchmarks in this study such as direct compensation and indirect compensation. Judging from the compensation received by employees of the University of West Nusa Tenggara giving monthly salaries and incentives to the lecturers.

Effect of Working Environment on Job Satisfaction. Based on the tests carried out from table 5, that the results of hypothesis testing from work environment variables show t-test of 2,129 with a significance level of 0,038 which is greater than the value of $t$ table $(t(\alpha / 2)(n-2)$ $=\mathrm{t}(0.05 / 2)(59-2)=\mathrm{t}(0.025,57)=\mathrm{t}$-table 2,002 then $\mathrm{Ho}$ is rejected and $\mathrm{Ha}$ is accepted, thus it can be concluded that the third hypothesis have a positive and significant influence between work environment on satisfaction of Lecturers at the University of West Nusa Tenggara, be accepted.

The results of this study support previous research conducted by Annakis et al., (2011), Sardzoska \& Tang (2012), Arta \& Harsono (2014), Plangiten (2013), Rizal (2015), the work environment has a significant effect on job satisfaction. Likewise with the research of Pangarso \& Rengganis (2015), the non-physical work environment has a significant effect on lecturer job satisfaction. While the results of this study are slightly different from the findings of Mu'at \& Juliana (2012), where the work environment simultaneously has a significant effect on job satisfaction, but partially no significant effect on job satisfaction. The results of this study are not supported by the research of Dhermawan, et al, (2013) and Suryana (2015), the work environment has no significant effect on job satisfaction. This suggests that job satisfaction can be influenced by many factors other than the work environment. If the work environment is good then there will be no problems with job satisfaction, and if the work environment is bad it will cause job dissatisfaction problems. This is reinforced by the opinion of Frederick Herzberg (1959) in Wirawan (2013) as has been revealed above the factors that 
influence job satisfaction include work conditions, work environment, subordinate supervisor relationships, and co-workers relationships.

\section{CONCLUSION}

In theory, there are many variables which can affect performance. However, the focus of this research is that performance can be influenced by situational leadership style, compensation and working environment. The results showed that leadership, compensation and working environment could influence the lecturer job satisfaction, so that the findings can contribute to the development of science in the field of Human Resource Management and can be a scientific reference for the future researchers.

In practical terms, this research contributed to the decision making of various parties, especially University of West Nusa Tenggara (UNTB) in knowing the performance of lecturers in campus. Situational leadership style influences lecturer job satisfaction, related to this matter, it is expected that the leadership of the University of West Nusa Tenggara (UNTB) will continue to apply effective situational leadership patterns so that the task for lecturers can be effective. Likewise with the pattern of relationship behavior, it is expected that the leaders of University of West Nusa Tenggara (UNTB) will continue to establish harmonious relations with lecturers so that various potential conflicts that may occur in campus environment can be resolved quickly and peacefully. Compensation affects the performance of lecturers, so it is expected to University of West Nusa Tenggara (UNTB) to provide fair and decent compensation to improve the welfare of the lecturers so that the lecturers become more enthusiastic and to encourage working performance and their performance.

Working environment is a factor that can affect the performance of lecturers so that they become more enthusiastic to do activities on campus. Therefore, it is expected that University of West Nusa Tenggara (UNTB) should pay more attention to their working environment by providing other facilities which can support their performance in order that they are more comfortable in the teaching process and enjoy being on campus environment.

\section{REFERENCES}

1. Agbozo, G.K., Owusu, I.S., Hoedoafia, M.H., \& Atakorah, Y.B. (2017). The Effect of Work Environment on Job Satisfaction: Evidence from the Banking Sector in Ghana. Journal of Human Resource Management, 5, (1), 12-18. doi: 10.11648/j.jhrm.20170501.12

2. Anas, K. (2013). Pengaruh kompensasi dan lingkungan kerja terhadap kepuasan kerja karyawan PT. Karya Mitra Muda. Jurnal Ekonomi.

3. Annakis, J., Lobo, A., \& Pillay, S. (2011). Exploring Monitoring, Work Environment And Flexibility As Predictors Of Job Satisfaction Within Australian Call Centres. International Journal of Business and Management. 6(8), 75-93.

4. Anoraga, P. (2009). Manajemen Bisnis. Semarang: PT. Rineka Cipta.

5. Arta, D.N.C., dan Harsono. (2014). Pengaruh Kepuasan Kompensasi Dan Lingkungan Kerja Terhadap Motivasi Serta Dampaknya Pada Kepuasan Kerja Karyawan Perusahaan Daerah Air Minum (PDAM) Kabupaten Bantul Daerah Istimewa Yogyakarta. Jurnal JBTI, 5 (2), 183-205.

6. As'ad, M. (2000). Psikologi Industri. Penerbit Lembaga Manajemen Akademi Manajemen Perusahaan YKPN. Yogyakarta.

7. Cahyo, V.A. (2016). Pengaruh Gaya Kepemimpinan Situasional Dan Komunikasi Internal Terhadap Kinerja Karyawan Di PT INTI (PERSERO) Bandung. Jurnal Ekonomi dan Bisnis.

8. Chen-Tsang (2011). Leadership, job satisfaction and service-oriented organizational citizenship behaviors in flight attendants. African Journal of Business Management, 5(5), 1915-1926. 
9. Darma, P.S., \& Supriyanto, A.S. (2017). The Effect of Compensation on Satisfaction and Employee Performance. Management and Economic Journal, 1 (1), 69-78. DOI: 10.18860/mec-j.v1i1.4524

10. Dhermawan, A.A.N.B., Sudibya, I.A., dan Utama, I.W.M. (2013). Pengaruh Motivasi, Lingkungan Kerja, Kompetensi, Dan Kompensasi Terhadap Kepuasan Kerja Dan Kinerja Pegawai Di Lingkungan Kantor Dinas Pekerjaan Umum Provinsi Bali. Jurnal Manajemen, Strategi Bisnis, dan Kewirausahaan, 6 (2), 173-184.

11. Fathonah, S dan Utami, I. (2010). Pengaruh Kompensasi, Pengembangan Karir, Lingkungan Kerja, dan Komitmen Organisasi terhadap Kepuasan Kerja Pegawai Sekretariat Daerah Kabupaten Karanganyar dengan Keyakinan Diri (Self Efficacy) sebagai Variabel Pemoderasi. E-Journal STIE AUB Surakarta.

12. Fonda, B., Utami, H.N., dan Ruhana, I. (2015). Pengaruh gaya kepemimpinan situasional terhadap budaya organisasi dan kepuasan kerja karyawan (Studi pada Karyawan PT. Telekomunikasi Indonesia Tbk. Wilayah Malang). Jurnal Administrasi Bisnis (JAB), 25 (1), 1-8.

13. Handoko, T.H. (2001). Manajemen Personalia dan Sumberdaya Manusia,Edisi Kedua. BPFE, Yogyakarta.

14. Handoko, T.H. (2004). Manajemen Personalia Dan Manajemen Sumber Daya Manusia. BPFE, Yogyakarta.

15. Hartanto, I. (2008). Pengaruh kepemimpinan dan budaya organisasi terhadap kinerja karyawan PT Air Mancur Wonogiri. Jurnal Muhammadiyah Surakarta.

16. Hasibuan, M.S.P. (2001)."Manajemen Sumber Daya Manusia”. Bumi Aksara, Jakarta.

17. Hersey, P., \& Blanchard, K. (2002). Management of Organization Behavior.

18. Ivancevich, J.M., Konopaske, R., \& Matteson, M.T. (2007). Perilaku dan Manajemen Organisasi (Alih bahasa: Wibi Hardani \& Bimo Adi Yoso). Jakarta. Erlangga.

19. Jai Prakash (2010). Effective Leadership and its Linear Dependence on Job Satisfaction: A Comparative Study in Public and Private Organization in India. Research Journal of Internatıonal Studies, 16.

20. Jex, S.M., \& Britt, T.W. (2002). Organizational Psychology: A Scientist Practitioner Approach. New York : John Wiley \& Sons.

21. Kertiriasih, N.R., Sujana, I.W., \& Suardika, I.N. (2018). The Effect of Leadership Style to Job Satisfaction, Employee Engagement and Employee Performance (Study at PT. Interbat, Bali, Nusra, and Ambon). International Journal of Contemporary Research and Review, 9 (3), 20592- 20600. doi: https://doi.org/10.15520/ijcrr/2018/9/03/468

22. Leshabari M, Muhondwa E, Mwangu M, Mbembati N. (2008). Motivation of Health care workers in Tanzania: case study of Muhimbili National Hospital. East African journal of Public Health, 5 (1): 30-36.

23. Luthans, F. (2002). Organizational Behavior, Ninth Edition. Singapore: McGraw- Hill International Editions.

24. Martoyo, S. (2000). Manajemen Sumber Daya Manusia. BPFE, Yogyakarta.

25. Marwansyah dan Mukaram. (2000). Manajemen Sumber Daya Manusia. Bandung: Pusat Penerbit Administrasi Niaga Politeknik Negeri Bandung

26. Mu'at, S., dan Juliana. (2012). Analisis Faktor-faktor yang Mempengaruhi Kepuasan Kerja Dosen UIN Suska Riau. Jurnal SOLUSI ISSN, 10 (3), 73-90.

27. Muguongo, M.M., Muguna, A.T., \& Muriithi, D.K. (2015). Effects of Compensation on Job Satisfaction Among Secondary School Teachers in Maara Sub-County of Tharaka Nithi County, Kenya. Journal of Human Resource Management, 3 (6), 47-59. doi:10.11648/j.jhrm.20150306.11

28. Murgijanto, E. (2015). Pengaruh Kompensasi Intrinsik Dan Kompensasi Ekstrinsik Terhadap Kepuasan Kerja Dosen Pada Sekolah Tinggi IImu Ekonomi AMA SALATIGA. Jurnal Among Makarti, 6 (11), 72-86.

29. Muttaqien, F. (2014). Pengaruh Kepemimpinan Dan Kompensasi Terhadap Kepuasan Kerja Karyawan Outsourcing pada PT. BRI (Persero), TBK. Cabang Lumajang. Jurnal WIGA, 4 (1), 19-33. 
30. Pangarso, A., dan Rengganis, R. (2015). Faktor-faktor budaya organisasi, suatu studi pada prodi administrasi bisnis (ADBIS)-Telkom University Bandung. DeReMa (Development Research of Management) Jurnal Manajemen, 10(2), 248-272.

31. Plangiten, P. (2013). Gaya kepemimpinan dan lingkungan kerja pengaruhnya terhadap kepuasan kerja karyawan pada PT. Pos Indonesia (Persero) Manado. Jurnal EMBA, 1 (4), 2155-2166.

32. Putranto, D.I. (2012). Pengaruh Komunikasi Internal, Kompensasi Kerja, dan Lingkungan Kerja Terhadap Kepuasan Kerja Karyawan pada PT. Kimia Farma Plant Semarang. Diponegoro Journal of Social and Politic.1-9.

33. Ramayanto. (2015). "Pengaruh Gaya Kepemimpinan, Kompensasi Dan Iklim Akademik Terhadap Komitmen Organisasi (Studi Pada Universitas Muhamadiyah Mataram), Tesis Universitas Mataram.

34. Rivai, V. (2010). Manajemen Sumber Daya Manusia untuk Perusahaan. Jakarta: Raja Grafindo Persada.

35. Rizal, F. (2015). Pengaruh Lingkungan Kerja Dan Kompensasi Terhadap Kepuasan Kerja Karyawan Pada PT. Statika Mitrasarana Padang. Jurnal Manajemen.

36. Robbins, S.P. (2008). Organizational Behaviour, Tenth Edition (Perilaku Organisasi Edisi ke Sepuluh), Alih Bahasa Drs. Benyamin Molan. Jakarta : Salemba Empat.

37. Robbins, S.P., dan Judge, (2008). Perilaku Organisasi, Salemba Empat, Jakarta.

38. Rusmanto. (2014). Pengaruh Gaya Kepemimpinan, Budaya Organisasi, Dan Kompensasi Terhadap Kinerja Karyawan Melalui Kepuasan Kerja Karyawan PR. Timun Mas Tunas Inti Nalumsari Jepara, Tesis Universitas Muria Kudus

39. Sardzoska, E.G., \& Tang. T.L. (2012). Work-Related Behavioral Intentions in Macedonia: Coping Strategies, Work Environment, Love of Money, Job Satisfaction and Demographic Variables. Journal of Business Ethics, 108 (3), 373-391.

40. Sari, A.P., dan Ardana. (2016). Peran Mediasi Kepuasan Kerja Pada Pengaruh Kompensasi Terhadap Kinerja Pekerja Kontrak. E-Jurnal Manajemen Unud, 5 (1), 470 499.

41. Sarwono, S. W. (2005). Psikologi Lingkungan, Penerbit PT. Gramedia Grasindo, Jakarta.

42. Slamet., Toyib, A., Hadiwidjojo, D., \& Troena, E. A. (2013). The Influence of Situational Leadership on Job Satisfaction and Job Performance (A Study on Trans Jakarta Bus way as Transportation Service in DKI Jakarta). Global Advanced Research Journal of Management and Business Studies, 2 (2), 105-113.

43. Sugiyarti, G. (2012). Pengaruh Lingkungan Kerja, Budaya Organisasi, dan Kompensasi terhadap Kepuasan Kerja untuk Meningkatkan Kinerja Pegawai (Studi pada Fakultas Ekonomi Universitas 17 Agustus 1945 Semarang). Jurnal IImiah UNTAG Semarang.

44. Suryana, E. (2015). Pengaruh Lingkungan Kerja, Kompensasi Dan Supervise Terhadap Kepuasan Kerja Bidan Pos Kesehatan Desa Di Kabupaten Lombok Barat. Tesis Universitas Mataram.

45. Triton P.B. (2005). Manajemen Sumber Daya Manusia. Tugu Publisher, Yoyagkarta.

46. Wirawan. (2013). Kepemimpinan: Teori, Psikologi, Perilaku Organisasi, Aplikasi dan Penelitian. Jakarta: PT. Raja Grafindo Persada

47. Wirda, F., dan Azra, T. (2012). Pengaruh gaya kepemimpinan situasional dan motivasi kerja terhadap kepuasan kerja Karyawan Politeknik Negeri Padang. Jurnal Polibisnis, 4 (1), 24-33. 